\title{
PSYCHOLOGICAL LITERACY OF TEACHERS IN THE ROLE OF YOUTH MENTORS
}

\author{
Marianna Berinšterová, Katarína Fuchsová, \& Monika Magdová \\ Institute of Pedagogy and Psychology, Faculty of Humanities and Natural Sciences \\ University of Presov (Slovakia)
}

\begin{abstract}
The concept of psychological literacy is important in education, but its use is lacking in Slovakia as well as mentoring relationships in school environment. Psychological literacy is defined as the ability to understand basic psychological principles and the ability to use these principles in practice. Mentoring of youth is understood as the existence of a nonparental significant adult who provides social support. Knowledge and skills needed for this role as part of psychological literacy should be included in the curriculum of education students.

The aim of the contribution was to explore the understanding of psychological literacy of teachers in Slovakia in terms of knowledge, competencies and attitudes, specifically for the role of the natural mentor of pupils.

Three focus groups were conducted with 18, 20 and 24 participants ( $82 \%$ of women; Mage=41,4; $68 \%$ of teachers have 15-20 years of practice) and two moderators in three regions of Slovakia. Participants were primary and secondary school teachers, selected based on willingness to participate in the research.

Six theoretical areas of psychological literacy were identified: (1) respecting psychological patterns in pedagogical practice; (2) counselling interview (3) competencies for cooperation in the school context; (4) commitment to the teaching profession; (5) life skills (critical thinking; self-regulation; social competence); (6) ability to handle stressful situations. These six theoretical areas will be the base for the Q-methodology creation and further for the preparation of theoretical model of psychological literacy of teachers.

Research will also contribute to the innovation of the psychological training of future teachers at universities in Slovakia. The understanding of the concept of mentoring in the school context and the role of a teacher as a mentor is discussed.
\end{abstract}

Keywords: Psychological literacy, teachers, education, mentoring.

\section{Introduction and objectives}

An interest in exploring psychological literacy has increased in recent years. The concept of psychological literacy is defined as "the general capacity to adaptively and intentionally apply psychology to meet personal, professional and societal needs" (Cranney, Botwood, Morris, 2012) and challenges (Roberts, Heritage, Gasson, 2015). More detailed conceptualisation McGovern et al. (2010) offers following elements:

(1) Understanding the basic concepts and principles of psychology;

(2) Thinking critically;

(3) Having problem-solving skills;

(4) Understanding scientific research practices;

(5) Communicating well in different contexts;

(5) Applying psychological principles to personal, social, or organizational problems;

(5) Acting ethically;

(6) Having cultural competence and respecting diversity;

(7) Having self and other awareness and understanding.

Research of psychological literacy is most often related to the study of psychological issues. British Psychological Society (BPS) states the following demands on the study of psychology: " $a$ coherent set of knowledge, skills and values that underpin students' psychological literacy and which enable them to apply psychology to real life contexts. (p.26). 
Psychological literacy of teachers is a specific topic in this case, given the multiple impact on cognitive, emotional and social development of children and adolescents. A teacher is not only a person who communicates information in a professional way. A teacher is a significant nonparental adult for many children and youth (Galbo, 1986; Galbo, Demetrulias, 1996). Supportive relationship with a nonparental significant adult is an important developmental asset. The needs of autonomy, competence and relatedness can be fulfilled in this relationship. In Slovakia, formal mentoring programs are rarely implemented and research of this area is minimally conducted.

However, the concept of psychological literacy of teachers is rarely mentioned and examined. In Slovakia, there is a need for innovations in the curricula of educational study programs. Increasing the capacity to be a natural mentor requires respect for functional and interactive psychological literacy (Sokolová, Lemešová, Jursová, Zacharová, 2014). Based on this knowledge, the aim of the research was formulated: to identify components that can form the concept of psychological literacy of teachers. The statements of teachers expressed in focus groups were used for the categorization of these components.

\section{Methods}

\subsection{Research sample}

The sample selection criterion was the geographical location due to the expectation of greater diversity of the absolved study preparation of teachers. For the needs of this research, 3 schools were selected, in pursuance of their willingness to participate in the research. In each school single focus group of teachers who educate pupils in the age of $11-15$ years ( 2 schools) and 15-19 years (1 school) was created.

Although the typical rule of focus groups is that participant don't know each other, our focus groups were created from colleagues who work together. Some research-based support for this approach can be found (Beckman, Haunschild, \& Phillips, 2004). Group dynamics of well-known participants and shared educational situation could contribute the creativity and expressing opinions, the essential parts of focus group research methods.

\subsection{The procedure of focus groups}

Research method of focus groups was conducted in June-July 2018 as a part of regular teambuilding activities for teachers at the end of the school year. Recommended methodological procedure was used (Švaříček, Šed'ová 2007). The same 2 persons facilitate the discussion in the all three groups. The process had the following phases:

(1) Opening phase. In this phase, the aim was to introduce the topic of the focus groups, research project, the way of data collection and analysis, the persons of moderators of the discussion (researchers) and explain the etical aspects of this research.

(2) Motivational phase. This phase consists of presentation of research results, that claim the multiple positive correlates of natural mentoring relationship of adolescents, while special attention was paid to the teacher in the role of natural mentor. In the end of the motivational part, psychological preparation of teachers was mentioned appealing to their own study experiences and profession needs in terms of the topic of focus groups.

(3) Discussion phase. Three questions were presented to teachers. Questions focused on knowledge, competencies and attitudes of teachers in the role of natural mentors.

- What kind of knowledge a teacher needs in the role of natural mentor?

- Imagine yourself in the role of natural mentor of pupils. Which competencies would you need to improve?

- $\quad$ Try to identify attitudes, that could be helpful for teachers in the role of mentor. Discussion was recorded with the permission of the participants.

(4) Ending phase. In this phase participants were invited to give the feedback to the course of focus group, facilitator approach, the topic and questions. The element of nonformal learning was added in the form of appreciation of the activity of the participants.

\section{Results}

Records of focus groups were transcribed and assessed by 3 researchers individually. Relevant issues in transcripts were labelled. Coding of the answers brings categories that are described below. Number and percentage of occurrence of these answers are listed. 
Table 1. Categories of answers on question 1: "What kind of knowledge a teacher needs in the role of natural mentor?".

\begin{tabular}{|c|c|c|}
\hline CATEGORIES OF ANSWERS & $\mathbf{N}$ & $\%$ \\
\hline 1. How to motivate pupils & 18 & 16.66 \\
\hline 2. Problem behaviour of children and adolescent & 16 & 14.81 \\
\hline 3. Behaviour disorders & 12 & 11.11 \\
\hline 4. Learning disabilities & 12 & 11.11 \\
\hline 5. How to handle aggression in the school context & 11 & 10.19 \\
\hline 6. Personality typologies & 9 & 8.33 \\
\hline 7. Stress situations and coping & 7 & 6.48 \\
\hline 8. Effective communication & 7 & 6.48 \\
\hline 9. Learning styles & 6 & 5.55 \\
\hline 10. Developmental specifics of pupils & 4 & 3.70 \\
\hline 11. Emotional intelligence & 4 & 3.70 \\
\hline 12. Gifted children & 2 & 1.85 \\
\hline
\end{tabular}

Answers for the first question were coded into 12 categories. Final number of answers was 108. The most occurred categories were "how to motivate children", "problem behaviour of children and adolescents" "behaviour disorders" and "learning disabilities".

Table 2. Categories of answers on question 2: "Imagine yourself in the role of natural mentor of pupils. Which competencies would you need to improve?".

\begin{tabular}{lc|c} 
CATEGORIES OF ANSWERS & N & \% \\
\hline 13. Ability to talk with pupils about their personal problem & 30 & 72.58 \\
\hline 14. Solving conflicts with pupils & 22 & 48.39 \\
\hline 15. Cooperation with pupils & 18 & 45.16 \\
\hline 16. Relaxation methods & 14 & 38.7 \\
\hline 17. Cooperation with parents & 14 & 38.7 \\
\hline 18. Coping with own negative emotions & 14 & 38.7 \\
\hline 19. Motivational interview & 12 & 30.65 \\
\hline 20. Self-control & 8 & 16.13 \\
\hline 21. Asking the right questions & 8 & 24.19 \\
\hline 22. Understanding of nonverbal communication & 9 & 15.51 \\
\hline 23. Cooperation with colleagues & 7 & 11.29 \\
\hline 24. Management of classes with diverse learning and behaviour & & \\
\hline disorders & 6 & 9.67 \\
\hline 25. Critical thinking & 3 & 4.83 \\
\hline 26. Ability to develop creativity of pupils & 3 & 4.83
\end{tabular}

Number of categories found in the answers to the question 2 is 14 . The total number of answers was 159 . Teachers most frequently stated that they would need to improve the ability to talk with pupils about their personal problems, the competence to solve conflicts with pupils, and the cooperation with them. 
Table 3. Categories of answers on question 3: "Try to identify attitudes, that could be helpful for teachers in the role of mentor".

\begin{tabular}{lc|c} 
& $\mathbf{N}$ & $\mathbf{\%}$ \\
\hline 27. Interest in the interaction with pupils not just during classes & 53 & 88.33 \\
\hline 28. Interest in learning outcomes of children & 31 & 51.66 \\
\hline 29. Openness toward parents of pupils & 25 & 41.66 \\
\hline 30. Openness to consultation with experts (psychologists, supervisors) & 4 & 6.66 \\
\hline 31. Willingness to learn new things & 3 & 4.54 \\
\hline &
\end{tabular}

The most frequented answer to the question concerning the attitude helpful for the teacher in the role of mentor was "interest in the interaction with pupils not just during classes". Overall, 5 categories were created from all 116 answers.

\subsection{Summary of categories and model proposal}

In the research, 31 categories of answers were identified. By summarising these categories and studying other researches (Canrinus, Helms-Lorenz, Beijaard, Buitink, Hofman,2012; Cranney, Morris, Botwood, 2015; Mangrulkar, Whitman, Posner, 2001; McGovern, Corey, Cranney, et al., 2010; Sharp, 2014; Rhodes, DuBois, 2008) in the area of mentoring and psychological literacy, components of psychological literacy of teachers in the role of mentor are proposed. These components are considered:

(1) respecting psychological patterns in pedagogical practice and knowledge from psychology

(2) counselling interview

(3) life skills - the ability of a person to behave adaptively in their interaction with the environment (critical thinking; self-regulation; cooperation in the school context; the ability to handle stressful situations)

(4) commitment to the teaching profession;

\section{Discussion and conclusion}

The aim of the contribution was to explore the understanding of psychological literacy of teachers in the role of natural mentors by the focus groups of 62 teachers. 31 categories of psychological literacy in terms of knowledge, competencies and attitudes were found and summarised to 4 components of specific model of psychological literacy. Research results point to the following:

The need of specific understanding of psychological literacy for the teaching profession. Conceptualisation of psychological literacy often highlights the reflection of psychological knowledge and its critical assessment (Coulson, Homewood, 2016). On the other hand, a significant part of the found categories was related to counselling interview, cooperation and own life skills (Mangrulkar, Whitman, Posner, 2001), and forming of professional relationships in the school context. Although relationship is professional, it is still an interpersonal relationship.

Perception of the aspects of natural mentoring relationships. Many teachers perceived themselves as educators rather than natural mentors. The research of mentoring in Slovakia is rare. There is a need for the deeper research of this area and dissemination of the results among teachers and youth workers.

One of the limits of the research was social desirability, especially in focus groups consisting of members that know each other. Furthermore, subjective views of researchers would impact the formation of categories of answers. Another research is needed to confirm the proposed components of psychological literacy of teachers.

The results of this contribution will be used for creation of Q methodology and another research of psychological literacy of teachers, and for innovation of study of education in Slovakia. According to Dunn, Cautin and Gurung (2011), the curricular change is needed in "education of educators", with balance between graduate and undergraduate needs. 


\section{References}

Beckman, C. M., Haunschild, P. R., \& Phillips, D. J. (2004). Friends or strangers? Firm-specific uncertainty, market uncertainty, and network partner selection. Organization science, 15(3), 259-275.

British Psychological Society (BPS) (2012b). The future of A-level psychology. Leicester: BPS. Retrieved 16.1.2019, from: http://www.bps.org.uk/system/files/

Canrinus, E. T., Helms-Lorenz, M., Beijaard, D., Buitink, J., \& Hofman, A. (2012). Self-efficacy, job satisfaction, motivation and commitment: exploring the relationships between indicators of teachers' professional identity. European journal of psychology of education, 27(1), 115-132.

Coulson, D., \& Homewood, J. (2016). Developing psychological literacy: is there a role for reflective practice? Journal of University Teaching \& Learning Practice, 13(2), 5.

Dunn, D. S., Cautin, R. L., \& Gurung, R. A. R. (2011). Curriculum matters: Structure, content, and psychological literacy. In J. Cranney \& D. S. Dunn (Eds.), The psychologically literate citizen: Foundations and global perspectives (pp. 15-26). New York, NY, US: Oxford University Press. Retrieved 25.2.2019 form http://dx.doi.org/10.1093/acprof:oso/9780199794942.003.0017

Cranney J, Botwood L, Morris S. (2012). National Standards for Psychological Literacy and GlobalCitizenship: Outcomes of Undergraduate Psychology. Office for Learning \& Teaching, Government of Australia. Sydney, NSW.

Cranney, J., Morris, S., \& Botwood, L. (2015). Psychological literacy in undergraduate psychology education. In Dunn, D.S. (Ed.). The Oxford handbook of undergraduate psychology education.

Galbo, J. J. (1986). Adolescents' perceptions of significant adults: Implications for the family, the school and youth serving agencies. Children and Youth Services Review, 8(1), 37-51.

Galbo, J. J., \& Demetrulias, D. M. (1996). Recollections of nonparental significant adults during childhood and adolescence. Youth \& Society, 27(4), 403-420.

McGovern TV, Corey L, Cranney J, et al. (2010). Psychologically literate citizens. In: Halpern, D.F., (ed). Undergraduate Education in Psychology: A Blueprint for the Future of the Discipline. Washington, DC: American Psychological Association, 9-27.

Rhodes,J. E., \& DuBois, D. L. (2008).Mentoring relationships and programs for youth. Current Directions in Psychological Science, 17, 254-258.

Roberts, L. D., Heritage, B., \& Gasson, N. (2015). The measurement of psychological literacy: a first approximation. Frontiers in psychology, 6, 105.

Sharp, P. (2014). Nurturing Emotional Literacy: A Practical for Teachers, Parents and those in the Caring Professions. London: Routledge.

Švaříček, R. Šed’ová K. a kol. (2007). Kvalitatívní výskum v pedagogických vědách. Praha: Portál, 384 s. ISBN 978-80-7367-313-0. 